Revista Eletrônica de Direito Processual - REDP. Volume 15. Janeiro a Junho de 2015 Periódico Semestral da Pós-Graduação Stricto Sensu em Direito Processual da UERJ. Patrono: José Carlos Barbosa Moreira. www.redp.com.br ISSN 1982-7636 PP 42-73

\title{
AS PRINCIPAIS QUESTÕES RELACIONADAS Às ASSOCIAÇÕES DE EMPREGADOS: UMA ANÁLISE ATUAL E CRÍTICA ${ }^{1}$
}

\author{
THE MAIN ISSUES RELATED TO THE WORKMEN'S \\ ASSOCIATIONS IN COURT: A CURRENT AND CRITICAL ANALYSIS
}

Carolina Tupinambá

Doutora em Direito Processual pela Universidade do Estado do Rio de Janeiro, Consultora e advogada na área trabalhista.carolina@tupinambaadvogados.com.br

Mariana Ferradeira

Mestranda em Direito Processual pela Universidade do Estado do Rio de Janeiro, Consultora e advogada.

RESUMO: Este artigo enfrentará de forma esmiuçada as principais questões relativas à atuação das associações de empregados em juízo. Será ressaltada a relevância dessa demanda coletiva no ordenamento jurídico para a defesa dos interesses de seus associados e serão abordados aspectos processuais, tais como os requisitos exigidos para a busca da tutela jurisdicional e os limites objetivos e subjetivos da decisão.

PALAVRAS-CHAVE: Associação de empregados. Atuação em juízo. Peculiaridades. Legitimidade. Requisitos. Benefícios. Limite objetivo. Limite subjetivo.

\begin{abstract}
This article shall approach, in detail, the main isssues related to the action of workmen's associations in court. The relevance of this collective action toward the legal framework for the defense of their member's interests shall be pointed out, and procedural aspects shall be broached, such as those required for seeking jurisdictional relief and the objective and subjective limits for decision-making.
\end{abstract}

\footnotetext{
${ }^{1}$ Artigo recebido em 12/02/2015 e aprovado em 29/04/2015.
} 
Revista Eletrônica de Direito Processual - REDP. Volume 15. Janeiro a Junho de 2015 Periódico Semestral da Pós-Graduação Stricto Sensu em Direito Processual da UERJ. Patrono: José Carlos Barbosa Moreira. www.redp.com.br ISSN 1982-7636 PP $42-73$

KEYWORDS: Workmen's associations. Action in court. Peculiarities. Legitimacy.

Requirements. Benefits. Objective Limit. Subjective Limit.

SUMÁRIO: I. A evolução da atuação das associações em defesa de direitos coletivos. II. A natureza das associações e a previsão estatutária para a atuação em juízo. III. Os benefícios da atuação associativa em juízo: a) a inexistência do empecilho de custos; b) o equilíbrio no que tange à capacidade postulatória; c) o incremento do poder de barganha e a "proteção contra dispensa". IV. Os fundamentos normativos da atuação associativa em juízo. V. A convivência da legitimidade dos sindicatos e das associações no processo do trabalho. VI. Os requisitos para a atuação judicial das associações. VI.1. Tempo de constituição; VI.2. Fins institucionais; VI.3. Pertinência temática; VI.4. Autorização dos substituídos. VII. O alcance dos efeitos da decisão em sede de ação coletiva proposta por associações. VIII. Conclusão. Referências Bibliográficas.

\section{A EVOLUÇÃO DA ATUAÇÃO DAS ASSOCIAÇÕES EM DEFESA DE DIREITOS COLETIVOS.}

É recente a relevância e a força com que tem atuado o chamado "terceiro setor"’2 na defesa de interesses ${ }^{3}$ transindividuais. Também é inegável que o papel exercido pelas entidades associativas para o desenvolvimento social, cultural, político e econômico do país ganha destaque a partir da incapacidade do Estado de suprir a demanda dos serviços sociais.

Nesse diapasão, esses corpos ou instâncias intermediárias são configurações sociais que nascem da tensão entre o indivíduo e a sociedade, da divergência entre o universal e o particular, configurando, de alguma forma, um modo indireto de inserção do indivíduo na totalidade social. Tais agentes podem se apresentar como grupos sociais, grupos de pressão, grupos intermediários, corpos intermediários, ou, ainda,

\footnotetext{
${ }^{2}$ Convencionou-se chamar de "primeiro setor" o Estado, de "segundo setor" as empresas privadas e, finalmente, de "terceiro setor" as organizações privadas sem fins lucrativos que geram ou produzem bens e serviços em áreas de relevante interesse público e social. É o caso das organizações não governamentais, das cooperativas, das associações e das fundações.

${ }^{3}$ A legislação específica, de forma indiscriminada, alterna os termos "direitos" e "interesses", que devem ser interpretados como sinônimos. Ambos têm o mesmo valor semântico quando mencionados pelo legislador, isto é, correspondem a uma prerrogativa ou direito subjetivo protegidos pelo sistema jurídico.
} 
Revista Eletrônica de Direito Processual - REDP. Volume 15. Janeiro a Junho de 2015 Periódico Semestral da Pós-Graduação Stricto Sensu em Direito Processual da UERJ. Patrono: José Carlos Barbosa Moreira. www.redp.com.br ISSN 1982-7636 PP $42-73$

instâncias intermediárias. São associações, sindicatos, entidades de classe, organizações não governamentais (ONGS) etc ${ }^{4}$.

Em geral, a finalidade comum será a base do agrupamento, podendo configurarse em interesse efêmero ou definitivo, de modo a criar ou manter a unidade do grupo. Será a capacidade de ação dirigida, de forma implícita ou explícita, para uma finalidade comum, aquilo que caracterizará o funcionamento de determinado grupo. É, portanto, a real possibilidade de se conseguir algo em virtude de ao grupo pertencer o maior de seus atrativos.

A lei n. ${ }^{\circ} 7.347 / 85$ (LACP) inovou ao permitir que as associações civis ${ }^{5}$ exercitassem a defesa de interesses transindividuais do grupo, classe ou categoria de pessoas que as integram. A previsão foi ratificada pela Constituição Federal e pelo Código de Defesa do Consumidor, de modo que, por meio de ação civil pública ou coletiva, têm as associações legitimidade para defender seus associados e não associados. A ampla liberdade associativa prevista na Carta é componente estimulante e imprescindível para a fórmula ${ }^{6}$

\footnotetext{
4 "Em todos os modelos de representação de interesses transindividuais, constata-se, em maior ou menor grau, a presença dos grupos organizados como entes aptos à tutela desses interesses. São os denominados corpos ou instâncias intermediárias, cuja presença na sociedade moderna acentua-se, gradativamente, com a adoção dos sistemas de democracia participativa". SANTOS, Ronaldo Lima dos. Sindicatos e Ações Coletivas: acesso à justiça, jurisdição coletiva e tutela dos interesses difusos, coletivos e individuais homogêneos. $4^{\mathrm{a}}$ ed., São Paulo: LTr, 2014.

${ }^{5}$ As associações civis são definidas pelo Código Civil como a união de pessoas que se organizam para fins não econômicos.

6 "A primeira Constituição política do Brasil a dispor sobre a liberdade de associação foi, precisamente, a Constituição republicana de 1891, e, desde então, essa prerrogativa essencial tem sido contemplada nos sucessivos documentos constitucionais brasileiros, com a ressalva de que, somente a partir da Constituição de 1934, a liberdade de associação ganhou contornos próprios, dissociando-se do direito fundamental de reunião, consoante se depreende do art. 113, § 12, daquela Carta Política. Com efeito, a liberdade de associação não se confunde com o direito de reunião, possuindo, em relação a este, plena autonomia jurídica (...). Diria, até, que, sob a égide da vigente Carta Política, intensificou-se o grau de proteção jurídica em torno da liberdade de associação, na medida em que, ao contrário do que dispunha a Carta anterior, nem mesmo durante a vigência do estado de sítio se torna lícito suspender o exercício concreto dessa prerrogativa. (...) Revela-se importante assinalar, neste ponto, que a liberdade de associação tem uma dimensão positiva, pois assegura a qualquer pessoa (física ou jurídica) o direito de associar-se e de formar associações. Também possui uma dimensão negativa, pois garante a qualquer pessoa o direito de não se associar, nem de ser compelida a filiar-se ou a desfiliar-se de determinada entidade. Essa importante prerrogativa constitucional também possui função inibitória, projetando-se sobre o próprio Estado, na medida em que se veda, claramente, ao Poder Público, a possibilidade de interferir na intimidade das associações e, até mesmo, de dissolvê-las, compulsoriamente, a não ser mediante regular processo judicial." (ADI 3.045, voto do Rel. Min. Celso de Mello, julgamento em 10-82005, Plenário, $D J$ de $1^{\circ}-6-2007$.)
} 
Revista Eletrônica de Direito Processual - REDP. Volume 15. Janeiro a Junho de 2015 Periódico Semestral da Pós-Graduação Stricto Sensu em Direito Processual da UERJ. Patrono: José Carlos Barbosa Moreira. www.redp.com.br ISSN 1982-7636 PP 42-73

A relevância desta tendência associativa, bem como de seus poderes judiciais, será tanto mais expressiva em cenários em que o indivíduo costuma ser mais frágil perante seu opoente, como no caso das relações travadas na seara trabalhista. ${ }^{7}$

A possibilidade de organização dos trabalhadores no local de trabalho, bem como o reconhecimento da legitimidade das associações de empregados para atuação em juízo ${ }^{8}$, pode ser entendida como um dos mais significativos expoentes da liberdade sindical, em elevado grau de maturidade e democracia sob o prisma das relações coletivas de trabalho.

\section{A NATUREZA DAS ASSOCIAÇÕES E A PREVISÃO ESTATUTÁRIA PARA A ATUAÇÃO EM JUÍZO.}

A representação dos trabalhadores em análise é tema relevante, de trato constitucional e em compasso com o caminho que vem sendo percorrido para o aperfeiçoamento da participação coletiva dos trabalhadores no ambiente da prestação de suas atividades laborais 9 .

São basicamente dois os modelos de representação dos trabalhadores na empresa: (i) modelo de representação unitária ou do sindicalismo extraempresarial. Segundo o qual os representantes são eleitos por todos os trabalhadores, independentemente de filiação ao sindicato, e os órgãos de representação estão desvinculados da estrutura sindical; e (ii) modelo sindical de representação, sistema

\footnotetext{
7 "Resta que os direitos de associação sindical e representação dos trabalhadores no local de trabalho são direitos fundamentais para equilibrar a desigual distribuição de poder nas relações de trabalho. Uma vez estruturados de forma livre, sem interferência limitadora da autonomia do grupo por parte do Estado e dos empregadores, com garantia de efetivo exercício da ação coletiva, transformam-se no centro de gravidade mais evoluído do direito do trabalho, funcionando como ponto de partida da negociação coletiva, entendida em seu sentido mais moderno, e, por conseguinte, de todo o sistema de relações de trabalho" SIQUEIRA, NETO, José Francisco. Liberdade sindical e representação dos trabalhadores nos locais de trabalho no Brasil: Obstáculos e Desafios, in Reforma Sindical e negociação coletiva. 1 ed., Brasília: OIT, 2001.

8 "É verdade que os poderes de representação de uma associação são mais restritos, se comparados com os conferidos aos sindicatos. Estes não se limitam apenas aos associados. Sua atuação destina-se à defesa dos direitos e interesses das pessoas visadas pelo estatuto, abrangendo toda a categoria, sem se limitar aos quadros associativos." ROMITA, Arion Sayão. “A representação dos trabalhadores na empresa”, in: Jurisprudência brasileira trabalhista - JBT 34, p. 19-30

9 “As primeiras manifestações do que hoje se denomina Organização (ou representação) no local de trabalho se deram como não poderia ser diferente, na Europa, no séc. XIX. Naquela época, nas nações com maior grau de industrialização, como Alemanha, Inglaterra, França e Bélgica, surgiram as comissões paritárias, com o objetivo específico de resolver questões atinentes às relações de trabalho, de modo a evitar deflagração de conflitos". COSTA, Carlos Eduardo Dantas. "Organização e Representação de trabalhadores no local de trabalho”, in: Revista LTr. São Paulo, ano 78, n. 06, junho de 2014, p. 696705.
} 
Revista Eletrônica de Direito Processual - REDP. Volume 15. Janeiro a Junho de 2015 Periódico Semestral da Pós-Graduação Stricto Sensu em Direito Processual da UERJ. Patrono: José Carlos Barbosa Moreira. www.redp.com.br ISSN 1982-7636 PP 42-73

que prevê a representação dos trabalhadores por órgãos sindicais instalados no interior das empresas.

Reconhecido como um direito fundamental do Estado democrático de direito, o artigo 11 do texto constitucional garante a representação dos trabalhadores nas empresas que tenham mais de duzentos empregados, com a finalidade exclusiva de promover " $o$ entendimento direto com os empregadores". Trata-se de representação inconfundível com a representação sindical. Nesta seara, o representante deve ser eleito pelos trabalhadores da empresa independentemente de qualquer vínculo com o sindicato da categoria atuante no âmbito territorial de situação da unidade produtiva ${ }^{10}$.

Em outras palavras, foi adotado o modelo de representação unitária no Brasil. As representações internas de trabalhadores surgiram principalmente a partir do "novo sindicalismo" que nasceu na região do ABC paulista, no final dos anos 1970 e início da década seguinte. A época foi marcada pela criação das verdadeiras comissões de fábrica no Brasil e pelas greves iniciadas em 1978, na Scania e na Ford, ambas em São Bernardo do Campo.

É importante registrar que o modelo de representação unitária não exclui a representação sindical, apenas facilita uma atuação fundada em ideologia de participação e colaboração com a empresa.

A ideia do representante ou mesmo de canais associativos pode ser traduzida como um porta-voz dos demais meios em comunicação com o empregador, com a finalidade de possibilitar entendimentos diretos entre o empregador e seus funcionários. Inexoravelmente, a vocação e o papel desempenhado pelo representante dos empregados deve ter uma índole voltada à negociação, abraçando a prevenção e a solução de conflitos.

As Convenções n. 98 e n. 154 da Organização Internacional do Trabalho - OIT tratam do tema. A primeira, relativa à aplicação dos princípios do direito de organização e de negociação coletiva, a segunda, sobre o incentivo à negociação coletiva, valoriza a convivência de modelos de representação extrassindical. Com semelhante preocupação, em 1971, a OIT editou, outrossim, a Convenção 135, ratificada pelo Brasil em 1991, por meio do Decreto 131, dispondo justamente sobre a liberdade sindical no plano da

\footnotetext{
${ }^{10}$ Importante destacar que, embora inicialmente a representação de trabalhadores no local de trabalho remeta ao art. 11, da Constituição Federal, a CLT, no art. $617, \S 1^{\circ}$, traz importante contribuição ao tema, afastando de forma irrefutável eventual vinculação ou subordinação que se pudesse fazer da genuína representação dos trabalhadores, caso das associações, em relação aos sindicatos.
} 
Revista Eletrônica de Direito Processual - REDP. Volume 15. Janeiro a Junho de 2015 Periódico Semestral da Pós-Graduação Stricto Sensu em Direito Processual da UERJ. Patrono: José Carlos Barbosa Moreira. www.redp.com.br ISSN 1982-7636 PP 42-73

empresa. A citada Convenção garante a proteção contra a eventual dispensa de representantes dos trabalhadores, assim considerados os representantes e delegados sindicais indicados pela entidade sindical ou os representantes e delegados de pessoal eleitos pelos trabalhadores da empresa.

$\mathrm{O}$ artigo $5^{\circ}$ da citada norma internacional preceitua que, se houver, de forma concomitante, representantes sindicais e delegados de pessoal eleitos pelos trabalhadores, deverão ser tomadas as medidas necessárias para garantir que a presença dos representantes eleitos não seja utilizada para o enfraquecimento da situação dos sindicatos interessados. A norma também estimula a cooperação para o enfrentamento de todas as questões pertinentes aos representantes eleitos e sindicatos interessados. Em suma, a Convenção n. 135 da OIT revela notória preocupação e cuidado com a harmonização e convivência da representação no âmbito da empresa e fora dela, em nível sindical.

A Convenção 135 da OIT é complementada pela Recomendação 143, que também prevê medidas de proteção dos representantes dos trabalhadores em nível interno, como, por exemplo, por meio da garantia à reintegração na hipótese de dispensa injusta. A Recomendação também dispõe sobre as facilidades para o exercício da função, destacando-se a preocupação com a garantia de tempo livre remunerado para o representante assistir a reuniões, cursos de formação, conferências etc.

Interessante notar que as Convenções n. 98 e n. 135, ambas ratificadas pelo Brasil, admitem a legitimidade de outros atores coletivos nas negociações, tais quais as associações de empregados.

A prerrogativa em análise é, todavia, limitada pelo texto constitucional, que atribui o papel exclusivamente para os sindicatos. A concessão do poder negocial foi reservada, pelo inciso VI do artigo $8^{\circ}$ da Constituição Federal, ao sindicato da categoria, reconhecido e registrado, afastando outros eventuais personagens das negociações coletivas, tais como as seções sindicais, os delegados e as comissões mistas admitidas pela CLT, bem como qualquer outro tipo de representação extrassindical de trabalhadores.

A participação dos trabalhadores no ambiente de trabalho constitui a democratização do processo produtivo, em seu aspecto econômico, administrativo, 
Revista Eletrônica de Direito Processual - REDP. Volume 15. Janeiro a Junho de 2015 Periódico Semestral da Pós-Graduação Stricto Sensu em Direito Processual da UERJ. Patrono: José Carlos Barbosa Moreira. www.redp.com.br ISSN 1982-7636 PP 42-73

social e político ${ }^{11}$. Trata-se de legítima hipótese de co-gestão: empregado e empregador desenhando, juntos, a participação nos lucros, a decisão sobre o processo de implantação de novas tecnologias, novos planos de carreira, programas sociais, procedimentos autocompositivos dos conflitos de interesses etc.

Em última análise, a participação dos trabalhadores no ambiente de trabalho aponta para o fim da intervenção Estatal, máxime pelas mãos do Poder Judiciário, nos ambientes restritos a realidades singulares como sói ser o local de trabalho. Daí, o direito fundamental de participação supõe, para a sua realização, a organização dos trabalhadores nos ambientes de exercício das tarefas laborais, o que significa dizer que é essencial a efetividade da liberdade de escolha de seus representantes para a formação das comissões de participação e de negociação. A importância de uma representação presente no ambiente de trabalho, nomeada autonomamente pelos trabalhadores, seja ela sindical ou não, em síntese, consiste no contato direto com as particularidades e os problemas da empresa e, por isso, o completo conhecimento da realidade encontrada na unidade produtiva.

A negociação no ambiente de trabalho através dos representantes dos trabalhadores em contínua presença na empresa contribui, outrossim, para o fim da estrutura autocrática ou da concepção hierárquica das relações trabalhistas, a qual tem, infelizmente, se operado mais afeta à submissão do que à comunicação. A participação dos trabalhadores no ambiente de trabalho prestigia o diálogo, favorece a exposição das opiniões dos trabalhadores, justamente as pessoas mais indicadas para conversar a propósito das dificuldades e dos problemas que são vivenciados na unidade produtiva, permitindo salutar e frutífera negociação espontânea. Trata-se de uma mudança de mentalidade e de modo de ver. Os processos participativos nos locais de trabalho importam majoração de oportunidades de crescimento social e econômico pela sinergia dos atores produtivos.

\footnotetext{
${ }^{11}$ Na obra Direito Sindical, Amauri Mascaro cita exemplos de fortes dispositivos garantidores do direito de representação de empregados pelo mundo afora. Aponta a Constituição de Weimar (Alemanha, 1891), como o princípio da ideia de cogestão nas empresas, com a participação dos trabalhadores por intermédio de comissões. Menciona, na Itália, em 1906, com o acordo firmado entre a Federação Italiana Operária Metalúrgica e a Fábrica de Automóveis Itália, de Torino (FIAT). Narra, na França, em 1885, os Conselhos de Usina; em 1889, os Delegados Operários, das Fábricas Schneider; e, em 1846, os representantes de Seção da Fábrica Gondin. Por fim, lembra os Conselhos de Salário Mínimo, de 1909, na Inglaterra, e os Conselhos de Cooperação Industrial, de 1922, na Espanha. Mais recentemente, já na União Europeia, a Diretiva n. 94/45, que regulamenta a representação dos trabalhadores, impondo seu reconhecimento aos Estados-membros, nas empresas com mais de 1.000 (mil) empregados. NASCIMENTO, Amauri Mascaro. Compêndio de Direito Sindical. São Paulo: LTr, 2005.
} 
Revista Eletrônica de Direito Processual - REDP. Volume 15. Janeiro a Junho de 2015 Periódico Semestral da Pós-Graduação Stricto Sensu em Direito Processual da UERJ. Patrono: José Carlos Barbosa Moreira. www.redp.com.br ISSN 1982-7636 PP 42-73

Conforme será tratado adiante, o estatuto da associação de empregados deve considerar expressamente a hipótese da atuação em juízo em favor de seus associados. É inafastável a conclusão de que o manejo das ações coletivas por associações gera diversas vantagens aos indivíduos, como a ampliação do acesso à Justiça, o maior equilíbrio entre as partes litigantes, a economia processual, o melhor resultado para relação custo-benefício, mais segurança jurídica, dentre outras.

Tal desígnio corrobora para dar vida à diretriz constitucional de implementação de uma democracia participativa e solidária com esteio no artigo $174, \S 2^{\circ}$ da Constituição Federal, assegurando proteção aos direitos de grupo.

\section{OS BENEFÍCIOS DA ATUAÇÃO ASSOCIATIVA EM JUÍZO.}

Atualmente no Brasil, a tutela jurisdicional dos direitos e interesses coletivos, em sentido amplo, se encontra largamente difundida dentro do direito objetivo. Além de contarmos com certa multiplicidade de instrumentos processuais, tais como ações de controle abstrato de constitucionalidade, ações populares, mandado de segurança coletivo, ações civis públicas, ações de improbidade, dissídios coletivos trabalhistas, processos-modelo nos incidentes de repercussão geral no STF e na lei de recursos repetitivos no STJ e, mais recentemente, no TST, dentre outros, o sistema ainda reconhece legitimidade a diversos órgãos e instituições para a defesa da tutela coletiva, tais como o Ministério Público, sindicatos, pessoas jurídicas de direito público, órgãos públicos sem personalidade jurídica, além, é claro, as associações.

$\mathrm{Na}$ seara trabalhista, existe um microssistema jurisdicional de direitos metaindividuais, composto por normas consagradas na (i) Constituição - artigos $5^{\circ}, 8^{\circ}$, 114 e 129; (ii) Lei orgânica do Ministério Público da União (LC 75/93); (iii) Lei de ação civil pública; (iv) Título III do CDC; (v) CLT e CPC e (vi) legislações especiais ${ }^{12}$.

A tutela coletiva, em geral, retrata importante e moderna forma de tutela jurisdicional de direitos. Particularmente na esfera trabalhista, as ações coletivas representam promessa de combate eficaz e incisivo pela erradicação da precarização de direitos de trabalhadores, pelo fim do trabalho escravo, pelo repúdio à discriminação no ambiente de trabalho. Tamanha magnitude de expectativas não dispensa, ainda, o papel institucional da tutela coletiva, haja vista que servil à ampliação do acesso à justiça, 12. Ver SANTOS, Enoque Ribeiro dos. “O Microssistema de Tutela Coletiva -
Parceirização Trabalhista” $L T r-2^{\text {a }}$ Ed. São Paulo. 2013. 
Revista Eletrônica de Direito Processual - REDP. Volume 15. Janeiro a Junho de 2015 Periódico Semestral da Pós-Graduação Stricto Sensu em Direito Processual da UERJ. Patrono: José Carlos Barbosa Moreira. www.redp.com.br ISSN 1982-7636 PP 42-73

através da (i) economia processual representada pela união de diversas demandas, (ii) uniformização das decisões judiciais sobre a mesma hipótese fática, em prol da igualdade diante da lei e da segurança do jurisdicionado, e (iii) isonomia material das partes no processo, alcançada pela reunião das partes hipoteticamente mais fracas da relação jurídica.

Admitir a legitimidade das associações para o ajuizamento de demandas coletivas na Justiça do Trabalho potencializa todo o leque de vantagens já natural das demandas coletivas.

Assim, defender a legitimidade associativa no processo trabalhista é posição combativa aos obstáculos que se apresentam contra a vivência mais ampla do acesso à Justiça, em quaisquer perspectivas que se entenda o conceito, é dizer: (i) como acesso substancial à justiça ou "efetividade" dos direitos sociais, que não devem ficar no nível das declarações meramente teóricas, mas atuar sobre a situação econômico-social dos indivíduos, e (ii) como busca de formas e métodos, muitas vezes novos e alternativos àqueles tradicionais, para a racionalização e controle da prestação jurisdicional. Em suma, a legitimidade das associações no processo correlaciona-se ao acesso a uma ordem jurídica justa, revitalizando possibilidades logísticas de ascensão à promessa representativa de um Direito voltado para a sociedade a que se destina, ampliando o direito de ação em demandas voltadas à estabilização de valores sociais prestigiados em um Estado Democrático de Direito.

As vantagens logísticas decorrentes do gerenciamento de ações trabalhistas por associações são muitas, mormente se considerado o contexto atual, em que inexiste uma defensoria pública preparada para intervir em lides trabalhistas. ${ }^{13}$ Como objetos de reflexão, destacam-se três conveniências, caso a opção adotada seja a judicialização dos dilemas em jogo. ${ }^{14}$

\section{a) A inexistência do empecilho de custos.}

A assistência jurídica garantida pela Constituição Federal abrange consultoria jurídica extrajudicial em geral e patrocínio gratuito de causas. A Justiça do Trabalho,

\footnotetext{
${ }^{13}$ As defensorias públicas estaduais existentes bem como a defensoria pública federal criada através da Lei Complementar n. ${ }^{\circ} 80$ de 1994, não oferecem assistência jurídica em conflitos de natureza trabalhista, função que, na prática, resta exclusivamente a cargo de alguns sindicatos, muitas vezes desaparelhados e desestruturados para tal mister.

${ }^{14}$ De forma mais extensa e detalhada, sobre a necessidade de processos supraindividuais e seus benefícios, consultar MENDES, Aluisio Gonçalves de Castro. "Ações coletivas e meios de resolução coletiva de conflitos no direito comparado e nacional", $3^{\text {a }}$ ed., São Paulo: Revista dos Tribunais, 2012, pp. $33-41$
} 
Revista Eletrônica de Direito Processual - REDP. Volume 15. Janeiro a Junho de 2015 Periódico Semestral da Pós-Graduação Stricto Sensu em Direito Processual da UERJ. Patrono: José Carlos Barbosa Moreira. www.redp.com.br ISSN 1982-7636 PP 42-73

dispensando formalidades e burocracias, em geral, concede aos (des)empregados que lá litigam a gratuidade. Todavia, será sempre um risco. Fato é que o empregado que ajuíza uma reclamação trabalhista individual estará sujeito à improcedência da mesma e, via de consequência, ao respectivo pagamento das custas, até mesmo para recorrer da decisão, caso a gratuidade seja negada. Por óbvio, a demanda viabilizada por órgãos de classe pulveriza o pretenso obstáculo a ponto de neutralizá-lo por completo, nos casos de custeio da causa pela própria associação com capital próprio arregimentado.

Embora de certo modo impertinente, é interessante apregoar que também a outra face da assistência jurídica é facilitada pelo associativismo, qual seja: a divulgação de informações e prestação de consultoria e esclarecimentos jurídicos. Após a vigência da Lei n. ${ }^{\circ}$ 10.537/2002, que reescreveu o artigo 790 da CLT, inexiste autorização legal para se supor que o sindicato seja o exclusivo órgão responsável pela prestação de assistência gratuita no processo do trabalho, razão pela qual devem ser estimulados o associativismo, a advocacia pro bono, os escritórios-modelo de universidades etc para o desempenho da atividade.

Outra vantagem interessante, também no que se refere ao ônus financeiro processual, diz respeito ao custeio de eventuais perícias como fator de intimidação do autor individual da reclamação trabalhista que eventualmente tenha como causa de pedir matérias relacionadas ao artigo 195 da CLT ou quaisquer outras questões em que necessária a prova técnica. Nesses cenários, também a coletivização poderá mostrar-se uma arma importante para que os trabalhadores prejudicados não sejam retraídos pela iminência de que a prestação judicial reste condicionada ao pagamento de perícia técnica.

\section{b) O equilíbrio no que tange à capacidade postulatória.}

O artigo 791 da CLT estabelece que tanto empregado como empregador podem defender seus interesses pessoalmente perante a Justiça do Trabalho. Aparentemente, o conteúdo do referido dispositivo seria decorrência da intentada simplicidade da postulação na seara laboral e de uma bem intencionada busca pelo mais amplo acesso à justiça, o que, na prática, não equivale à realidade.

Em abril de 2010, o Superior Tribunal do Trabalho editou o enunciado n. 425 de sua jurisprudência sumulada consolidando que "o jus postulandi das partes, estabelecido no art. 791 da CLT, limita-se às Varas do Trabalho e aos Tribunais Regionais do Trabalho, não alcançando a ação rescisória, a ação cautelar, o mandado 
Revista Eletrônica de Direito Processual - REDP. Volume 15. Janeiro a Junho de 2015 Periódico Semestral da Pós-Graduação Stricto Sensu em Direito Processual da UERJ. Patrono: José Carlos Barbosa Moreira. www.redp.com.br ISSN 1982-7636 PP 42-73

de segurança e os recursos de competência do Tribunal Superior do Trabalho." O cenário permite litígios que contraponham um único empregado frente a frente com o empregador e uma penca de advogados ao seu lado. São conflitos que decorrem de relação jurídica assimétrica, marcada pela vulnerabilidade da parte lesada, o empregado, sob o prisma fático, econômico e jurídico.

A potencial atuação da parte em juízo sem advogado viola o princípio igualitário, pois as sociedades comparecem em juízo com advogados preparados tecnicamente, conhecedores de questões processuais, enquanto o trabalhador, via de regra, não tem condições de, sozinho, bem defender seu direito judicialmente. O ajuizamento de ações coletivas por associações, por sua vez, em geral, presume assistência técnica de alta qualidade, pesquisada e ranqueada no mercado, custeada em rateio pós-licitação de profissionais diferenciados, que são atraídos por demandas concentradas de direitos de massa, na expectativa de boa aferição de lucros em tempo e esforços mais focados.

\section{c) O incremento do poder de barganha e a "proteção contra dispensa".}

Em singela e intuitiva avaliação, o trabalhador, no curso da relação de trabalho, não tem plena liberdade para judicializar eventual impasse vivenciado em seu emprego. Possui justificado receio de ser demitido.

As relações de trabalho são balizadas pela subordinação, que, em contexto de elevada disparidade de distribuição de bens, torna mais frágil a posição do trabalhador que pretenda reivindicar seus direitos, mas tema a tal despedida injustificada.

A questão traduz uma espécie de desigualdade de partes. É que, de um lado, o empregador não tem nada a perder ao optar por um litígio judicial e, de outro, o empregado deve estar disposto a abrir mão do emprego para propor uma ação trabalhista. Isso porque, como a relação de emprego é baseada na confiança, o empregador tende a imediatamente demitir o empregado que ajuíza uma ação contra ele.

De outra banda, caso espere o fim do vínculo empregatício para demandar seu direito, é certo que só fará jus ao que for devido nos últimos cinco anos.

Dita constatação é um dos elementos que concorreram para que a legitimidade extraordinária dos sindicatos já fosse reconhecida no art. 513, “ $a$ ”, da CLT, interpretada como tentativa de se evitar o receio legítimo de que a condenação, obtida em ação coletiva, fosse frustrada pela inibição dos beneficiados em impulsionar, 
Revista Eletrônica de Direito Processual - REDP. Volume 15. Janeiro a Junho de 2015 Periódico Semestral da Pós-Graduação Stricto Sensu em Direito Processual da UERJ. Patrono: José Carlos Barbosa Moreira. www.redp.com.br ISSN 1982-7636 PP $42-73$

individualmente, a execução do julgado, tendo-se em vista pressões em sentido contrário impingidas pelos empregadores.

Neste contexto, o ajuizamento de ação trabalhista por empregado com contrato em curso pode ser viabilizado com mais segurança e menos temor por eventual represália, se assim levada a cabo com seus pares, via ação coletiva proposta por associação de trabalhadores.

A demanda coletiva acaba por robustecer o poder de barganha dos trabalhadores que necessitam permanecer empregados, mas não querem deixar escapar a chance de correção de alguma prática trabalhista equivocada em desproveito da classe.

\section{OS FUNDAMENTOS NORMATIVOS DA ATUAÇÃO ASSOCIATIVA EM JUÍZZO.}

A verificação da legitimidade da parte é uma condição para o julgamento do mérito de uma ação. Aprioristicamente, terá legitimidade o titular do interesse em relação à outra parte.

Excepcionalmente, a lei processual brasileira admite, em seu artigo $6^{\circ}$, a legitimação extraordinária, consagrando, assim, a figura do substituto processual. Em outras palavras, a legitimação extraordinária confere a alguém legitimidade para, em nome próprio, agir em juízo na defesa de direito alheio, contrariando a regra geral do artigo $3^{\circ}$ e a primeira parte do próprio artigo $6^{\circ}$ do CPC.

Como exceção à regra que é, a substituição processual demanda expressa autorização legal. No caso das associações, a própria Constituição Federal confere a legitimidade para atuação judicial em favor da coletividade ${ }^{15}$.

No chamado "microssistema de processo coletivo" ao qual já fizemos referência, a Lei da Ação Civil Pública ${ }^{16}$, o Código de Defesa do Consumidor $^{17}$ e a Lei do

\footnotetext{
15 Transcreve-se, com destaques:

Art. $5^{\circ}$ Todos são iguais perante a lei, sem distinção de qualquer natureza, garantindo-se aos brasileiros e aos estrangeiros residentes no País a inviolabilidade do direito à vida, à liberdade, à igualdade, à segurança e à propriedade, nos termos seguintes:

XXI - as entidades associativas, quando expressamente autorizadas, têm legitimidade para representar seus filiados judicial ou extrajudicialmente;

LXX - o mandado de segurança coletivo pode ser impetrado por:

a) partido político com representação no Congresso Nacional;

b) organização sindical, entidade de classe ou associação legalmente constituída e em funcionamento há pelo menos um ano, em defesa dos interesses de seus membros ou associados;

${ }^{16}$ Lei n. 7.347/85, Lei da Ação Civil Pública:
} 
Revista Eletrônica de Direito Processual - REDP. Volume 15. Janeiro a Junho de 2015 Periódico Semestral da Pós-Graduação Stricto Sensu em Direito Processual da UERJ. Patrono: José Carlos Barbosa Moreira. www.redp.com.br ISSN 1982-7636 PP $42-73$

Mandado de Segurança ${ }^{18}$ regulamentam a legitimidade processual das associações para

o ajuizamento de ações coletivas.

Ademais, no início do século, com o desenhar de um arcabouço sistemático de processos coletivos, surgiu na doutrina especializada a ideia de um Código Modelo de

Processos Coletivos para Ibero-américa. Durante o VII Seminário Internacional coorganizado pelo "Centro di Studi Giuridici Latino Americani" da "Università degli Studi di Roma - Tor Vergata", pelo "Istituto Italo-Latino Americano" e pela “ Associazione di Studi Sociali Latino-Americani” foi apresentada proposta amadurecida pela diretoria do Instituto Ibero-Americano. A partir de então foi encomendado um Código que pudesse servir não só como repositório de princípios, mas também como

Art. $5^{\circ}$ Têm legitimidade para propor a ação principal e a ação cautelar: (Redação dada pela Lei $n^{\circ}$ 11.448, de 2007).

I - o Ministério Público; (Redação dada pela Lei n 11.448, de 2007).

II - a Defensoria Pública; (Redação dada pela Lei no 11.448 , de 2007).

III - a União, os Estados, o Distrito Federal e os Municípios; (Incluído pela Lei n ${ }^{\circ} 11.448$, de 2007).

IV - a autarquia, empresa pública, fundação ou sociedade de economia mista; (Incluído pela Lei $\mathrm{n}^{\circ}$ 11.448, de 2007).

V - a associação que, concomitantemente: (Incluído pela Lei n ${ }^{\circ} 11.448$, de 2007).

a) esteja constituída há pelo menos 1 (um) ano nos termos da lei civil; (Incluído pela Lei no 11.448 , de 2007).

b) inclua, entre suas finalidades institucionais, a proteção ao patrimônio público e social, ao meio ambiente, ao consumidor, à ordem econômica, à livre concorrência, aos direitos de grupos raciais, étnicos ou religiosos ou ao patrimônio artístico, estético, histórico, turístico e paisagístico. (Redação dada pela Lei $\mathrm{n}^{\circ}$ 13.004, de 2014)

$\S 1^{\circ} \mathrm{O}$ Ministério Público, se não intervier no processo como parte, atuará obrigatoriamente como fiscal da lei.

$\S 2^{\circ}$ Fica facultado ao Poder Público e a outras associações legitimadas nos termos deste artigo habilitarse como litisconsortes de qualquer das partes.

$\S 3^{\circ}$ Em caso de desistência infundada ou abandono da ação por associação legitimada, o Ministério Público ou outro legitimado assumirá a titularidade ativa. (Redação dada pela Lei no 8.078, de 1990)

$\S 4 .^{\circ} \mathrm{O}$ requisito da pré-constituição poderá ser dispensado pelo juiz, quando haja manifesto interesse social evidenciado pela dimensão ou característica do dano, ou pela relevância do bem jurídico a ser protegido. (Incluído pela Lei $\mathrm{n}^{\mathrm{a}} 8.078$, de 11.9.1990)

(...)

${ }^{17}$ Lei n. 8.078/90, Código de Defesa do Consumidor:

Art. 82. Para os fins do art. 81, parágrafo único, são legitimados concorrentemente: (Redação dada pela Lei $n^{\circ}$ 9.008, de 21.3.1995)

I - o Ministério Público,

II - a União, os Estados, os Municípios e o Distrito Federal;

III - as entidades e órgãos da Administração Pública, direta ou indireta, ainda que sem personalidade jurídica, especificamente destinados à defesa dos interesses e direitos protegidos por este código;

IV - as associações legalmente constituídas há pelo menos um ano e que incluam entre seus fins institucionais a defesa dos interesses e direitos protegidos por este código, dispensada a autorização assemblear.

${ }^{18}$ Lei n. 12.016/09:

Art. 21. O mandado de segurança coletivo pode ser impetrado por partido político com representação no Congresso Nacional, na defesa de seus interesses legítimos relativos a seus integrantes ou à finalidade partidária, ou por organização sindical, entidade de classe ou associação legalmente constituída e em funcionamento há, pelo menos, 1 (um) ano, em defesa de direitos líquidos e certos da totalidade, ou de parte, dos seus membros ou associados, na forma dos seus estatutos e desde que pertinentes às suas finalidades, dispensada, para tanto, autorização especial. 
Revista Eletrônica de Direito Processual - REDP. Volume 15. Janeiro a Junho de 2015 Periódico Semestral da Pós-Graduação Stricto Sensu em Direito Processual da UERJ. Patrono: José Carlos Barbosa Moreira. www.redp.com.br ISSN 1982-7636 PP 42-73

modelo concreto para inspirar as reformas, de modo a tornar mais homogênea a defesa dos interesses e direitos transindividuais em países de cultura jurídica comum. O projeto final foi apresentado e transformado em Anteprojeto nas Jornadas Ibero-Americanas de Direito Processual, de Montevidéu, em outubro de 2002. Após a incorporação de sugestões de professores integrantes de comissão revisora, restou aprovado o Código Modelo de Processos Coletivos para Ibero-América nas XIX Jornadas IberoAmericanas de Direito Processual, em outubro de 2004, em Caracas. A fonte normativa também regulamenta a legitimidade das associações, conforme se infere do trecho copiado abaixo, com destaques:

Art. $3^{0}$. Legitimação ativa. São legitimados concorrentemente à ação coletiva:

(...)

VIII - as associações legalmente constituídas há pelo menos um ano e que incluam entre seus fins institucionais a defesa dos interesses e direitos protegidos neste código, dispensada a autorização assemblear.

Par. $1^{\circ}$. O requisito da pré-constituição pode ser dispensado pelo juiz, quando haja manifesto interesse social evidenciado pela dimensão ou característica do dano, ou pela relevância do bem jurídico a ser protegido.

A defesa de direitos de índole coletiva por entidades associativas tem, portanto, ampla previsão legal. A seguir, serão traçadas e enfrentadas as condições para o exercício do direito de ação pelas associações.

\section{A CONVIVÊNCIA DA LEGITIMIDADE DOS SINDICATOS E DAS} ASSOCIAÇÕES NO PROCESSO DO TRABALHO.

Dada a pluralidade de instrumentos para a tutela jurisdicional dos direitos e interesses coletivos prevista no ordenamento brasileiro, primeiramente, convém delimitarmos nossa análise às ações coletivas que sejam da competência da Justiça do Trabalho, de acordo com o artigo 114 da Constituição Federal, as quais podem ser divididas em dois grandes grupos: (i) os dissídios coletivos e (ii) as demais possíveis ações coletivas de qualquer outra natureza procedimental. No que tange a todas as outras formas de tutela de direitos coletivos perante a Justiça do Trabalho, que não os 
Revista Eletrônica de Direito Processual - REDP. Volume 15. Janeiro a Junho de 2015 Periódico Semestral da Pós-Graduação Stricto Sensu em Direito Processual da UERJ. Patrono: José Carlos Barbosa Moreira. www.redp.com.br ISSN 1982-7636 PP $42-73$

dissídios, as associações detêm legitimidade para atuar em juízo em defesa da coletividade $^{19}$.

Obviamente, a defesa dos interesses coletivos na esfera trabalhista costuma ser intentada pelas associações sindicais em defesa dos membros da categoria que representa, com pertinência temática presumida. Mais frequentes como clientes da Justiça do Trabalho, os sindicatos atuam como substitutos, de acordo com previsões legislativas expressas, tais quais:

i. Quando na demanda trabalhista houver pedido de adicional de periculosidade ou insalubridade, de acordo com o artigo 195 da CLT, parágrafo $2^{\circ}$;

ii. Para propositura de ação de cumprimento de sentença normativa, conforme disposto no artigo 872 da CLT, parágrafo único, bem como na súmula n. 286 do TST;

iii. Para propositura de mandado de segurança coletivo, previsto na Constituição Federal no artigo $5^{\circ}$, inciso LXX, b;

iv. $\quad$ Para cobrança de FGTS, de acordo com a lei n. 8.036/90;

v. Finalmente, para defesa de interesses e direitos coletivos da categoria, ou mesmo individuais, em questões administrativas ou judiciais - como dispõe o artigo $8^{\circ}$, III da Constituição Federal do Brasil combinado com a lei n. 8.073/90, art. $3^{\circ}$.

Divergências sobre as possibilidades de substituição processual sindical levaram o TST a editar a famosa súmula n. 310, que restringia bastante a participação processual dos sindicatos como substitutos.

Todavia, após decisões havidas no Supremo Tribunal Federal a respeito da matéria, ainda que incidenter tantum, que conferiram ampla interpretação ao texto constitucional que autoriza a atuação sindical como substituto processual, o TST, por intermédio da Resolução n. 121/03, cancelou a súmula n. 310, dando uma trégua a todos os inúmeros empecilhos, formalidades e requisitos para que o sindicato atuasse como substituto processual. Não obstante, convém confessar que, mesmo sem o apoio da súmula, a visão do TST continuou tímida e retraída acerca da legitimidade sindical como substituto processual.

Posteriormente, o STF, quando da apreciação do Recurso Extraordinário de n. 210.029-RS ${ }^{20}$, cujo objeto era justamente a definição das possibilidades de substituição

\footnotetext{
${ }^{19}$ Ver Borba, Joselita Nepomuceno. Legitimidade concorrente: inexistência de monopólio do sindicato na defesa de interesses de integrantes da categoria. In: Revista do Ministério Público do Trabalho, v. 21, n. 43, p. 128-152, mar. 2012.
} 
Revista Eletrônica de Direito Processual - REDP. Volume 15. Janeiro a Junho de 2015 Periódico Semestral da Pós-Graduação Stricto Sensu em Direito Processual da UERJ. Patrono: José Carlos Barbosa Moreira. www.redp.com.br ISSN 1982-7636 PP 42-73

processual pelo sindicato, foi provocado a manifestar-se com índole mais certeira que as declarações obter dictum outrora esboçadas. Afirmou, definitivamente, como questão principal do recurso, o entendimento de que o sindicato pode, sim, atuar na defesa de todos e quaisquer direitos subjetivos individuais e coletivos dos integrantes da categoria por ele representada. A interpretação em tela foi a mais ampla possível.

Desse modo, restou inócuo diante do pronunciamento cristalino da Corte Suprema o conteúdo do artigo 859 da CLT, que estabelece que, para que haja tal substituição, é necessária a autorização em assembleia, da qual participem os associados interessados na solução do dissídio coletivo e de acordo com o quórum ali especificado.

Em suma, os sindicatos, excluídos os dissídios de natureza econômica, em que funcionam como partes legitimadas ordinariamente, atuam como substitutos processuais na defesa de direitos alheios, mesmo aqueles individuais.

As associações nem tanto. Em verdade, não se pode equiparar a substituição processual prevista para os sindicatos com a das associações. É que, no caso das associações, a própria Constituição Federal estabelece expressamente que as entidades associativas têm legitimidade para representar seus filiados judicial ou extrajudicialmente apenas quando expressamente autorizadas. A legislação especial traz outros requisitos e, como visto, o Código de Defesa do Consumidor dispensa autorização assemblear. Em outras palavras: a questão é tormentosa.

\section{OS REQUISITOS PARA A ATUAÇÃO JUDICIAL DAS ASSOCIAÇÕES.}

O texto da Carta apregoa que as entidades associativas têm legitimidade para representar seus filiados judicial ou extrajudicialmente. $\mathrm{O}$ alcance da expressão equivale

\footnotetext{
${ }^{20}$ DJe-082 DIVULG 16-08-2007 PUBLIC 17-08-2007

EMENTA: PROCESSO CIVIL. SINDICATO. ART. $8^{\circ}$, III DA CONSTITUIÇÃO FEDERAL. LEGITIMIDADE. SUBSTITUIÇÃO PROCESSUAL. DEFESA DE DIREITOS E INTERESSES COLETIVOS OU INDIVIDUAIS. RECURSO CONHECIDO E PROVIDO. O artigo $8^{\circ}$, III da Constituição Federal estabelece a legitimidade extraordinária dos sindicatos para defender em juízo os direitos e interesses coletivos ou individuais dos integrantes da categoria que representam. Essa legitimidade extraordinária é ampla, abrangendo a liquidação e a execução dos créditos reconhecidos aos trabalhadores. Por se tratar de típica hipótese de substituição processual, é desnecessária qualquer autorização dos substituídos. Recurso conhecido e provido.
} 
Revista Eletrônica de Direito Processual - REDP. Volume 15. Janeiro a Junho de 2015 Periódico Semestral da Pós-Graduação Stricto Sensu em Direito Processual da UERJ. Patrono: José Carlos Barbosa Moreira. www.redp.com.br ISSN 1982-7636 PP $42-73$

dizer que as associações podem figurar como substitutas processuais em determinadas hipóteses. $^{21}$

Em verdade, o titular da ação relativa a interesses coletivos exerce uma função pública. Para alguns autores, melhor que a "substituição processual" é a expressão "legitimação autônoma"22, pela simples razão de que, tratando-se da aplicação ou mesmo da criação do direito objetivo, não há "substituídos". Tratando de interesses ou direitos coletivos stricto sensu, o legitimado ativo exerceria função pública em favor do grupo, categoria ou classe. Não haveria, portanto, "representação", nem "substituição processual", mas, de fato uma "presentação". 23

A partir de outro ponto de observação, é possível se extrair que o termo representação extraído do texto constitucional contém carga limitativa de atuação:

"Se a legitimação é para "representar seus filiados", um limite de atuação fica desde logo patenteado: o objeto material da demanda deve ficar circunscrito aos direitos e interesses desses filiados. Um outro limite é imposto pelo interesse de agir da instituição legitimada: sua atuação deve guardar relação com seus fins institucionais." 24

Para o Superior Tribunal de Justiça, o traço que distingue os institutos da substituição e da representação processual é o fato de, no primeiro, o substituto ser parte no processo e não necessitar de autorização dos substituídos para atuar em juízo, ao passo que, no segundo, o representante não é parte e precisa de autorização para representar:

AGRAVO INTERNO. RECURSO ESPECIAL. PROCESSUAL CIVIL. AÇÃO CIVIL PÚBLICA AJUIZADA POR ASSOCIAÇÃO OBJETIVANDO A DEFESA DE DIREITO

\footnotetext{
${ }^{21}$ O STJ recusou, por exemplo, a possibilidade de uma associação civil defender em juízo interesses de grupo de associados que contrariassem os de outro grupo de associados, por malferir em parte seu fim institucional. Ver STJ, 2. ${ }^{a}$ T., RMS 15.311 / PR, rel. Min. Eliana Calmon, j. 20.03.03.

${ }^{22} \mathrm{O}$ fenômeno está inserido na chamada legitimação extraordinária autônoma e não deve ser confundido com a simples representação, pois, nesta, o próprio alegado titular do direito material é parte no processo. Ver essa e as demais classificações, no direito nacional e comparado, em MENDES, Aluisio Gonçalves de Castro. "Ações coletivas e meios de resolução coletiva de conflitos no direito comparado e nacional", $3^{\mathrm{a}}$ ed., São Paulo: Revista dos Tribunais, 2012, pp. 27 e 28.

23 TESHEINER, José Maria. "Aplicação do Direito objetivo e tutela de direitos subjetivos nas ações transindividuais e homogeneizantes". In Revista Brasileira de Direito Processual - RBDPro, Belo Horizonte: Editora Fórum, ano 20, n. 78, 13-28, abr/jun. 2012.

${ }^{24}$ ZAVASKI, Teori Albino. Processo Coletivo - tutela de direitos coletivos e tutela coletiva de direito. $5^{\text {a }}$ edição. São Paulo: Editora Revista dos Tribunais. 2012. p. 162/163
} 
Revista Eletrônica de Direito Processual - REDP. Volume 15. Janeiro a Junho de 2015 Periódico Semestral da Pós-Graduação Stricto Sensu em Direito Processual da UERJ. Patrono: José Carlos Barbosa Moreira. www.redp.com.br ISSN 1982-7636 PP 42-73

INDIVIDUAL DISPONÍVEL DE DETERMINADOS

ASSOCIADOS. IMPOSSIBILIDADE.

SUBSTITUIÇÃO PROCESSUAL NÃO AUTORIZADA.

1.- Não se confundem os institutos da substituição e da representação processual. Na substituição a Associação age em nome próprio e não depende de autorização de seus filiados para ajuizar ação na defesa de seus direitos coletivos e individuais homogêneos.

Já na representação, os filiados integram o polo ativo da ação, dependendo o seu ajuizamento, pela Associação, da autorização daqueles.

2.- Impossibilidade de ajuizar-se ação civil pública para a defesa de direitos individuais disponíveis de parcela dos associados.

Precedentes.

3.- Agravo Regimental improvido.

(AgRg no REsp 1213290/PR, Rel. Ministro SIDNEI BENETI, TERCEIRA TURMA, julgado em 19/08/2014, DJe 01/09/2014)

Em verdade, a redação constitucional, ao dispor que "as entidades associativas, quando expressamente autorizadas, têm legitimidade para representar seus filiados judicial ou extrajudicialmente", não goza de grande primor científico. De fato, discussões acadêmicas em torno do termo "representar" pouco terão a agregar na prática, uma vez desvendado o objetivo do dispositivo, que é justamente possibilitar a tutela de interesses e direitos coletivos através da ação associativa.

Portanto, as associações estão legitimadas para o ajuizamento de ações coletivas na defesa de direitos difusos, coletivos e individuais homogêneos, podendo, inclusive, propor ações diretas de inconstitucionalidade (art. $2^{\circ}$, IX, Lei n. $\left.{ }^{\circ} 9.868 / 99\right)^{25}$.

$\mathrm{O}$ reconhecimento e alcance da legitimidade ad processum das associações subordina-se a certos requisitos, que serão a seguir relacionados.

Em diversos sistemas processuais com mais tradição na tutela de interesses coletivos, tal como o vigente nos Estados Unidos, Canadá e Reino Unido, a legitimidade do autor coletivo é perquirida caso a caso, averiguando-se a denominada

25 "A associação de classe, de âmbito nacional, há de comprovar a pertinência temática, ou seja, o interesse considerado o respectivo estatuto e a norma que se pretenda fulminada." (ADI 1.873, Rel. Min. Marco Aurélio, julgamento em 2-9-1998, Plenário, $D J$ de 19-9-2003.) 
Revista Eletrônica de Direito Processual - REDP. Volume 15. Janeiro a Junho de 2015 Periódico Semestral da Pós-Graduação Stricto Sensu em Direito Processual da UERJ. Patrono: José Carlos Barbosa Moreira. www.redp.com.br ISSN 1982-7636 PP 42-73

"adequacy of representation" ou "representação adequada" diante do caso concreto, o que importa praticamente uma fase do processo independente e por vezes deveras longa, na qual se pretende avaliar se a entidade ou outro autor coletivo detém fundamentos, meios e qualidade técnica para a demanda que intenta.

Entre nós, o processo coletivo brasileiro adotou um regime de legitimidade extraordinária em que os substitutos processuais são indicados prévia e abstratamente pela lei, o que significa dizer que se trata de uma legitimidade ope legis.

Há, portanto, uma presunção de representatividade adequada das associações civis para o ajuizamento de ações civis públicas ou coletivas, bem como para a intervenção como litisconsortes ou assistentes litisconsorciais no polo ativo, quando preenchidos os requisitos a seguir mencionados (pré-constituição há pelo menos um ano, vocação e pertinência temática), de modo que com muito menos rigor verificamos a "qualidade" da representação, se em comparação com os ordenamentos supracitados.

\section{VI.1. TEMPO DE CONSTITUIÇÃO.}

Ainda que o requisito possa ser afastado, de acordo com decisões pontuais derivadas do amadurecimento do debate pelo Superior Tribunal de Justiça, é necessário, em regra, para que se viabilize a substituição processual pela associação, que a mesma tenha sido regularmente constituída há no mínimo um ano.

\section{VI.2. FINS INSTITUCIONAIS.}

Em segundo lugar, mister que as associações que pretendam litigar em favor de associados incluam entre seus fins institucionais a defesa dos interesses e direitos difusos, coletivos e individuais homogêneos ${ }^{26}$.

A jurisprudência tem sido firme em rechaçar a atuação judicial associativa em defesa de indivíduos isolados. Assim, para configuração de legitimidade ativa e de

\footnotetext{
${ }^{26}$ Ver PINHO, Humberto Dalla Bernardina de. "Direito Processual Civil Contemporâneo", vol. I, $5^{\text {a }}$ ed., Rio de Janeiro: Saraiva, 2013, p.720, 724 e 725. Os direitos transindividuais não são estáticos, na medida em que refletem a pretensão de uma coletividade em constante mutação, e não admitem uma classificação definitiva. Não obstante a crítica, o nosso ordenamento os conceitua, respectivamente, como (i) direitos com as características básicas de indeterminação dos sujeitos, indivisibilidade do objeto, intensa conflituosidade e duração efêmera; (ii) direitos individuais indivisíveis agrupados ou feixe de interesses individuais da totalidade dos membros de uma entidade ou de parte deles, que são, portanto, determinados ou determináveis e estão ligados entre si ou com a parte contrária por uma relação jurídica base e não por circunstâncias fáticas, como ocorre no caso dos direitos difusos; (iii) direitos singulares, próprios de cada pessoa e, por isso, divisíveis, decorrentes de fato comum, que, por motivos de interesse social, podem ser tutelados coletivamente.
} 
Revista Eletrônica de Direito Processual - REDP. Volume 15. Janeiro a Junho de 2015 Periódico Semestral da Pós-Graduação Stricto Sensu em Direito Processual da UERJ. Patrono: José Carlos Barbosa Moreira. www.redp.com.br ISSN 1982-7636 PP 42-73

interesse processual da associação, faz-se necessário que a inicial da lide demonstre ter por objeto a defesa de direitos difusos, coletivos ou individuais homogêneos. ${ }^{27}$

\section{VI.3. PERTINÊNCIA TEMÁTICA.}

Deverá haver, ainda, pertinência temática entre o objeto da lide e o objetivo associativo, o que significa dizer que, especificamente no caso da propositura da ação por associações, exige-se um liame entre o substituto processual e matéria discutida em juízo. Seria uma ligação por afinidade, notadamente com as finalidades institucionais do autor da ação coletiva.

Dita condição não pode ser dispensada pelo magistrado, ao contrário do requisito da pré-constituição, ou melhor, do lapso estipulado entre a constituição e a propositura da demanda. A pertinência temática significa que as associações civis devem incluir entre seus fins institucionais a defesa dos interesses objetivados na ação civil pública ou coletiva por elas propostas. É a adequação entre o objeto da ação e a finalidade institucional.

Em outras palavras, a vocação da entidade deve ser voltada propriamente à defesa dos direitos dos associados, o que não significa necessariamente dizer que o direito que ilustre o objeto litigioso tenha vínculo com os fins institucionais, como esclarece o trecho destacado no acórdão abaixo:

“CONSTITUCIONAL. PROCESSUAL CIVIL. MANDADO DE SEGURANÇA COLETIVO. SUBSTITUIÇÃO PROCESSUAL. AUTORIZAÇÃO EXPRESSA. OBJETO A SER PROTEGIDO PELA SEGURANÇA COLETIVA. C.F., art. 5º LXX, 'b'.

I. - A legitimação das organizações sindicais, entidades de classe ou associações, para a segurança coletiva, é extraordinária, ocorrendo, em tal caso, substituição processual. C.F., art. $5^{\circ}$, LXX.

II. - Não se exige, tratando-se de segurança coletiva, a autorização expressa aludida no inciso XXI do art. $5^{\circ}$ da Constituição, que contempla hipótese de representação.

III. - O objeto do mandado de segurança coletivo será um direito dos associados, independentemente de guardar vínculo com os fins

\footnotetext{
${ }^{27}$ Nesse sentido, STJ, 4a T., REsp n. ${ }^{\circ}$ 823063. Rel. Min. Raul Araújo, j. 14.02.2012.
} 
Revista Eletrônica de Direito Processual - REDP. Volume 15. Janeiro a Junho de 2015 Periódico Semestral da Pós-Graduação Stricto Sensu em Direito Processual da UERJ. Patrono: José Carlos Barbosa Moreira. www.redp.com.br ISSN 1982-7636 PP 42-73

próprios da entidade impetrante do writ, exigindo-se, entretanto, que o direito esteja compreendido na titularidade dos associados e que exista ele em razão das atividades exercidas pelos associados, mas não se exigindo que o direito seja peculiar, próprio, da classe. IV. - R.E. conhecido e provido" (RE 193.382/SP, Relator o Ministro Carlos Velloso, Tribunal Pleno, DJ 20.9.1996).

Conclui-se, pelo excerto supratranscrito, que a finalidade institucional deve ser compatível com a defesa do interesse transindividual que a associação pretende tutelar em juízo e pode ser razoavelmente genérica; não é preciso que uma associação civil seja constituída para defender em juízo especificamente aquele exato interesse controvertido na hipótese concreta. ${ }^{28}$ Essa generalidade não pode ser desarrazoada, sob pena de ser admitida a criação de uma associação civil para a defesa de qualquer interesse, o que desnaturaria a exigência de representatividade adequada do grupo lesado.

$\mathrm{Na}$ prática, o que se percebe é que o processo coletivo brasileiro adota um sistema híbrido de aferição de legitimidade, pois, além da prévia autorização legal para a propositura da ação coletiva (legitimação ope legis), deve o autor demonstrar a préconstituição nos termos da lei civil há pelo menos um ano e a pertinência temática vocacionada de sua atuação, de modo a ser considerado, no caso concreto, um representante adequado.

\section{VI.4. AUTORIZAÇÃO DOS SUBSTITUÍDOS.}

Além dos requisitos (i) pré-constituição há pelo menos um ano; (ii) previsão institucional; e (iii) pertinência temática; tem se exigido autorização expressa para atuação em juízo. No passado, a exigência era abrandada e diversas vezes chegou a ser superada nos tribunais superiores.

Ressalte-se que, particularmente, para a propositura de mandado de segurança coletivo, o requisito será despiciendo ${ }^{29}$. Do mesmo modo, a autorização dos associados

\footnotetext{
${ }^{28}$ Já se entendeu, por exemplo, que uma associação civil que tenha por finalidade a defesa do consumidor pode propor ação coletiva em favor de participantes que tenham desistido de consórcio de veículos, não se exigindo tenha sido instituída para a defesa específica de interesses de consorciados de veículos, desistentes ou inadimplentes. Ver MAZZILLI, Hugo Nigro. "A Defesa dos Interesses Difusos em Juízo: meio ambiente, consumidor, patrimônio cultural, patrimônio público e outros interesses". 22ed. Rev, ampl. E atual. - São Paulo: Saraiva, 2009, p. 309/310

29 "O inciso LXX do art. $5^{\circ}$ da CF encerra o instituto da substituição processual, distanciando-se da hipótese do inciso XXI, no que surge no âmbito da representação. As entidades e pessoas jurídicas nele mencionadas atuam, em nome próprio, na defesa de interesses que se irradiam, encontrando-se no
} 
Revista Eletrônica de Direito Processual - REDP. Volume 15. Janeiro a Junho de 2015 Periódico Semestral da Pós-Graduação Stricto Sensu em Direito Processual da UERJ. Patrono: José Carlos Barbosa Moreira. www.redp.com.br ISSN 1982-7636 PP 42-73

(individual ou coletiva) será desnecessária ainda que a ação verse sobre direito de apenas parte deles, de acordo com enunciado de súmulas da jurisprudência consolidada no Supremo Tribunal Federal, se não vejamos:

SÚMULA 629 A impetração de mandado de segurança coletivo por entidade de classe em favor dos associados independe da autorização destes.

SÚMULA 630 A entidade de classe tem legitimação para o mandado de segurança ainda quando a pretensão veiculada interesse apenas a uma parte da respectiva categoria.

Para as associações sindicais, como dissemos, também não se aplica o requisito. Na Suprema Corte, especificamente no julgamento dos RE 210.029-RS e RE 193.503$\mathrm{SP}$, restou consignado que a legitimidade extraordinária dos sindicatos para defender em juízo os direitos e interesses coletivos ou individuais dos integrantes da categoria que representam seria ampla, não podendo ser limitada à autorização dos substituídos, abrangendo, inclusive, a liquidação e a execução dos créditos reconhecidos.

Para as ações, que não as de segurança, ajuizadas por entidades associativas, a questão chegou a ser afetada como de repercussão geral. O Supremo Tribunal Federal assentou com força vinculativa que, para promover execuções na qualidade de substituta processual, as associações devem apresentar autorização de cada um de seus filiados. Com tema afetado desde 2008, o entendimento foi pacificado recentemente no julgamento do RE 573.232 30 . Ementa nos seguintes termos, com destaques:

\title{
RE 573232 / SC - SANTA CATARINA \\ Relator(a): Min. RICARDO LEWANDOWSKI
}

\begin{abstract}
patrimônio de pessoas diversas. Descabe a exigência de demonstração do credenciamento." (RMS 21.514, Rel. Min. Marco Aurélio, julgamento em 27-4-1993, Segunda Turma, DJ de 18-6-1993.)

30 “(...) o Plenário, em conclusão de julgamento, e por votação majoritária, proveu recurso extraordinário no qual se discutia a legitimidade ativa de associados que, embora não tivessem autorizado explicitamente a associação a ajuizar a demanda coletiva, promoveram a execução de sentença prolatada em favor de outros associados que, de modo individual e expresso, teriam fornecido autorização para a entidade atuar na fase de conhecimento (...). No mérito, reafirmou a jurisprudência da Corte quanto ao alcance da expressão 'quando expressamente autorizados', constante da cláusula inscrita no mencionado inciso XXI do art. $5^{\circ}$ da $\mathrm{CF}$. Asseverou que esse requisito específico acarretaria a distinção entre a legitimidade das entidades associativas para promover demandas em favor de seus associados (CF, art. $\left.5^{\circ}, \mathrm{XXI}\right)$ e a legitimidade das entidades sindicais ( $\mathrm{CF}$, art. $\left.8^{\circ}, \mathrm{III}\right)$. O Colegiado reputou não ser possível, na fase de execução do título judicial, alterá-lo para que fossem incluídas pessoas não apontadas como beneficiárias na inicial da ação de conhecimento e que não autorizaram a atuação da associação, como exigido no preceito constitucional em debate. Ademais, a simples previsão estatutária de autorização geral para a associação seria insuficiente para lhe conferir legitimidade. Por essa razão, ela própria tivera a cautela de munir-se de autorizações individuais." (RE 573.232, rel. p/ o ac. min. Marco Aurélio, julgamento em 145-2014, Plenário, Informativo 746, com repercussão geral.)
\end{abstract}


Revista Eletrônica de Direito Processual - REDP. Volume 15. Janeiro a Junho de 2015 Periódico Semestral da Pós-Graduação Stricto Sensu em Direito Processual da UERJ. Patrono: José Carlos Barbosa Moreira. www.redp.com.br ISSN 1982-7636 PP 42-73

Relator(a) p/ Acórdão: Min. MARCO AURÉLIO

Julgamento: $14 / 05 / 2014$

Órgão Julgador: Tribunal Pleno

Publicação 19-09-2014

REPRESENTAÇÃO - ASSOCIADOS - ARTIGO 5, INCISO XXI, DA CONSTITUIÇÃO FEDERAL. ALCANCE. O disposto no artigo $5^{\circ}$, inciso XXI, da Carta da República encerra representação específica, não alcançando previsão genérica do estatuto da associação a revelar a defesa dos interesses dos associados. TÍTULO EXECUTIVO JUDICIAL - ASSOCIAÇÃO - BENEFICIÁRIOS. As balizas subjetivas do título judicial, formalizado em ação proposta por associação, é definida pela representação no processo de conhecimento, presente a autorização expressa dos associados e a lista destes juntada à inicial.

Em verdade, a Suprema Corte já exigia deliberação assemblear para a propositura legitimada do litígio ${ }^{31}$. Desde julgamento datado de março de 2000, o Supremo Tribunal Federal já havia abalizado que seriam requisitos cumulativos (i) a cláusula estatutária de autorização e (ii) a manifestação autorizativa específica do órgão deliberativo máximo, sendo desnecessária a juntada de procuração individual em ação ordinária ou em mandado de segurança coletivo. Tal julgamento tornou-se histórico, pois foi a partir dele que restou clara a permissão para a representação coletiva de associações - pelo menos expressamente em relação à ação ordinária coletiva independentemente de autorização individual, bastando a constante dos estatutos e da assembleia geral:

“CONSTITUCIONAL. ADMINISTRATIVO. PROCESSUAL CIVIL. SUPREMO TRIBUNAL FEDERAL: COMPETÊNCIA ORIGINÁRIA: C.F., art. 102, I, n. AÇÃO ORDINÁRIA COLETIVA: LEGITIMAÇÃO: ENTIDADE DE CLASSE: AUTORIZAÇÃO EXPRESSA: C.F., art. 5', XXI. SERVIDOR PÚBLICO: REMUNERAÇÃO: CORREÇÃO MONETÁRIA. I. -

${ }^{31}$ Rcl 5215 AgR / SP - SÃO PAULO AG.REG.NA RECLAMAÇÃO Relator(a): Min. CARLOS BRITTO Julgamento: 15/04/2009 
Revista Eletrônica de Direito Processual - REDP. Volume 15. Janeiro a Junho de 2015 Periódico Semestral da Pós-Graduação Stricto Sensu em Direito Processual da UERJ. Patrono: José Carlos Barbosa Moreira. www.redp.com.br ISSN 1982-7636 PP $42-73$

Ação ordinária em que magistrados do Rio Grande do Sul pleiteiam correção monetária sobre diferença de vencimentos paga com atraso. Interesse geral da magistratura gaúcha no desfecho da ação. Competência originária do Supremo Tribunal Federal: C.F., art. 102, I, n. II. - Ação ordinária coletiva promovida por entidade de classe: C.F., art. $5^{\circ}$, XXI: inexigência de autorização expressa

dos filiados. Voto vencido do Relator: aplicabilidade da regra inscrita no art. $5^{\circ}$, XXI, da C.F.: necessidade de autorização expressa dos filiados, não bastando cláusula autorizativa constante do Estatuto da entidade de classe. III. - Diferença de vencimentos paga com atraso: cabimento da correção monetária, tendo em vista a natureza alimentar de salários e vencimentos. Precedentes do S.T.F. IV. - Ação conhecida e julgada procedente" (AO 152, Rel. Min. Carlos Velloso, Tribunal Pleno, DJ 3.3.2000). (Negritou-se) ${ }^{32}$

Trata-se, conforme já destacou o Supremo Tribunal Federal, de orientação afinada com os requisitos estabelecidos também no parágrafo único do art. $2^{\circ}$-A da Lei n. 9.494/97, que determina a instrução da petição inicial de ações coletivas propostas contra a União, os Estados, o Distrito Federal, os Municípios e suas autarquias e fundações com a "ata da assembleia da entidade associativa que a autorizou, acompanhada da relação nominal dos seus associados e indicação dos respectivos endereços".

Tais requisitos seriam não condição da ação, mas pressupostos processuais para aferição da capacidade da associação para estar no processo em defesa de direitos individuais homogêneos de seus membros. Assim, podemos afirmar que, com o julgamento do recurso excepcional n. 573232 dotado de repercussão geral e à exceção

\footnotetext{
32 Assim publicado no informativo n. 162 do STF: "Retomando o julgamento de ação ordinária de cobrança ajuizada pela Associação dos Juízes do Rio Grande do Sul - AJURIS que fora remetida ao STF tendo em vista o interesse de todos os membros da magistratura gaúcha (v. Informativo 152), o Tribunal, preliminarmente, decidiu, por maioria, que a autorização para que as entidades associativas tenham legitimidade para representar seus filiados judicialmente tem que ser expressa (CF, art. $\left.5^{\circ}, \mathrm{XXI}\right)$, sendo necessária, além da previsão genérica em seu estatuto, a ata da assembléia geral que conferiu à associação poderes específicos para a demanda. Com esse entendimento, o Tribunal conheceu da ação relativamente a todos os magistrados associados da autora à época dos fatos. Vencido em parte o Min. Carlos Velloso, relator, que conhecia da ação apenas quanto aos litisconsortes ativos e aos magistrados que firmaram as autorizações constantes dos autos, por entender que o art. $5^{\circ}$, XXI, da CF não dispensa a autorização expressa de cada um dos associados, e que a decisão tomada por maioria na assembléia geral no sentido de autorizar a AJURIS a promover tal ação não bastaria para representar todos os seus filiados judicialmente, já que a ata não menciona quais associados que divergiram. AO 152-RS, rel. Min. Carlos Velloso, 15.9.99."
} 
Revista Eletrônica de Direito Processual - REDP. Volume 15. Janeiro a Junho de 2015 Periódico Semestral da Pós-Graduação Stricto Sensu em Direito Processual da UERJ. Patrono: José Carlos Barbosa Moreira. www.redp.com.br ISSN 1982-7636 PP 42-73

do mandado de segurança coletivo, passa a ser prudente que o ajuizamento de ação coletiva por associação se faça acompanhar de: (i) autorização expressa dos associados; (ii) lista dos beneficiários, (iii) além da ata da assembleia e do estatuto que comprove o fim institucional.

De acordo com o entendimento do Supremo, seria exatamente esta a pedra de toque que diferenciaria a "substituição processual", por sindicato a dispensar o requisito e a "representação", pela associação a exigir autorização dos possíveis beneficiados pela tutela demandada.

Em verdade, a leitura do inteiro teor do julgamento do Recurso Extraordinário n. 573.232, em sede de repercussão geral, permite apreender que o Supremo Tribunal Federal reafirmou o entendimento de que o texto constitucional exige autorização expressa para as associações demandarem em juízo, mas que não há qualquer restrição quanto à forma de comprovação desta aquiescência. Ela poderá, destarte, ser concedida por ato individual ou por deliberação em assembleia, detalhada a ata neste sentido.

Por cautela extrema, recomenda-se a juntada de autorização assemblear juntamente com instrumento individual, sendo certo que dita precaução blindará a ação contra eventual extinção sem resolução do mérito por conta de hipotética ilegitimidade.

\section{O ALCANCE dOS EFEITOS DA DECISÃO EM SEDE DE AÇÃO COLETIVA PROPOSTA POR ASSOCIAÇÕES}

Os limites subjetivos da coisa julgada em ação coletiva proposta por entidade associativa estão em vias de ser definitivamente sedimentados no julgamento do Tema n. 499 da Repercussão Geral do Supremo Tribunal Federal, cujo leading case é o Recurso Extraordinário n. 612.043 de relatoria do Ministro Marco Aurélio ${ }^{33}$.

Nesse processo, discute-se justamente se os efeitos da coisa julgada em execução de sentença proferida em ação ordinária de caráter coletivo ajuizada por entidade associativa abrangem somente os filiados à data da propositura da ação ou também os que, no decorrer do processo, alcançaram essa qualidade.

\footnotetext{
${ }^{33}$ REPERCUSSÃO GERAL EM RE N. 612.043-PRRELATOR: MIN. MARCO AURÉLIO AÇÃO COLETIVA - SUBSTITUIÇÃO PROCESSUAL - ARTIGO $5^{\circ}$, INCISO XXI, DA CARTA DE 1988 - ALCANCE TEMPORAL - DATA DA FILIAÇÃO. Possui repercussão geral a controvérsia acerca do momento oportuno de exigir-se a comprovação de filiação do substituído processual, para fins de execução de sentença proferida em ação coletiva ajuizada por associação - se em data anterior ou até a formalização do processo.
} 
Revista Eletrônica de Direito Processual - REDP. Volume 15. Janeiro a Junho de 2015 Periódico Semestral da Pós-Graduação Stricto Sensu em Direito Processual da UERJ. Patrono: José Carlos Barbosa Moreira. www.redp.com.br ISSN 1982-7636 PP 42-73

O Ministério Público Federal, intimado a se manifestar no recurso extraordinário afetado, defendeu a extensão do título judicial a todos os filiados que se amoldem ao dispositivo transitado em julgado, ainda que a data de filiação tenha sido posterior à fase cognitiva do processo. A interpretação do órgão, portanto, é a menos restritiva possível $^{34}$.

Os nomes constantes de listas ou autorização expressa assemblear, por óbvio, estarão vinculados pelo sucesso ou fracasso da ação coletiva. Em relação aos demais associados, não será possível se afirmar ao certo.

Como se sabe, uma demanda coletiva não impede o ajuizamento de ação individual relativa ao mesmo objeto, já que "entre nós vigora o princípio da integral liberdade de adesão ou não ao processo coletivo, que, em caso positivo, deve ser expressa e inequívoca por parte do titular do direito", compreendendo-se, nessa liberdade de adesão, "a liberdade de promover ou de prosseguir a ação individual, simultânea à ação coletiva", bem como a de "executar ou não, em seu favor, a sentença de procedência resultante da ação coletiva" 35 .

De acordo com o artigo 104 do CDC, a coisa julgada decorrente da sentença de procedência proferida na ação coletiva, como regra geral, beneficia os autores das demandas individuais concomitantemente propostas, salvo se estes, cientificados da existência da lide coletiva, tiverem optado pelo prosseguimento das ações por eles manejadas.

\footnotetext{
${ }^{34}$ É o que se depreende dos seguintes trechos do parecer ministerial, com destaques:

A partir dessa constatação, é possível vislumbrar que a associação age em substituição processual, autorizada por lei, na defesa de direito e interesse alheio, consoante artigo $6^{\circ}$ do CPC, c/c artigo $5^{\circ}$, inciso $\mathrm{XXI}$, da CF/88.

Assim, na oportunidade, não há eficácia reflexa da coisa julgada, artigo $42, \S 3^{\circ}$, do $\mathrm{CPC}$, sendo do substituído o direito material disputado.

Assim, é consequente a aferição de que a prestação da tutela jurisdicional, comum aos substituídos, está em perfeita sintonia com o contraditório e a ampla defesa, pois a decisão definitiva proferida sobre o bem da vida, objeto do litígio, estende-se, inclusive, àqueles que, apresentando mesma identidade de fato $\mathrm{e}$ pedido, filiaram-se após a fase cognitiva, sem que haja qualquer prejuízo aos limites subjetivos e objetivos da coisa julgada.

(...) Daí, infere-se que, uma vez filiado, ainda que a posteriori, os efeitos do decisum, ocorrendo identidade de fato e pedido, o alcançará, seja para o bônus, quanto para o ônus, impedindo que se discuta a justiça da decisão.

Destarte, a substituição processual jamais se instituiria para tornar-se instrumento de tumulto ou até mesmo de previsível entrave à prestação jurisdicional. Nesse espeque, há que transcender a interpretação restritiva do texto da lei para alçar um sentido teleológico do sistema normativo, mormente quando o fato de se estar filiado antes da ação, no presente caso, é irrelevante, não podendo o exegeta deixar de ponderar as consequências na vida prática.

${ }^{35}$ Teori Albino Zavascki. Processo Coletivo. 2006, p. 17
} 
Revista Eletrônica de Direito Processual - REDP. Volume 15. Janeiro a Junho de 2015 Periódico Semestral da Pós-Graduação Stricto Sensu em Direito Processual da UERJ. Patrono: José Carlos Barbosa Moreira. www.redp.com.br ISSN 1982-7636 PP 42-73

$\mathrm{O}$ associado, portanto, que tenha ação individual em curso poderá seguir com sua demanda normalmente, restando automaticamente excluído da coisa julgada da ação coletiva. Se bom ou ruim não será atingido.

Aquele associado que requerer a suspensão de seu processo individual no prazo de 30 dias será beneficiado pela coisa julgada favorável da ação coletiva ou, no caso de insucesso da mesma, poderá tocar sua demanda outrora ajuizada. Isso significa dizer que, se a ação coletiva não der certo, o associado que requereu a suspensão da sua ação individual poderá voltar à demanda e até ganhar ${ }^{36}$.

Ainda sobre a litispendência, é pertinente ressaltar que o instituto não poderá ser aferido da forma como previsto no artigo $301, \S \S 1^{\circ}$ e $2^{\circ}$, do $\mathrm{CPC}$, haja vista que devem ser considerados os interessados, ou seja, os substituídos e não a parte formal, o legitimado. ${ }^{37}$

Os associados sem referência de nome na ação coletiva, de acordo com a atual jurisprudência, não serão atingidos pela coisa julgada, haja vista que as balizas subjetivas do título judicial, formalizado em ação proposta por associação, são definidas pela representação no processo de conhecimento, presente a autorização expressa dos associados e a lista destes juntada à inicial. ${ }^{38}$

\footnotetext{
${ }^{36}$ Ver RR - 54200-22.2004.5.02.0038, Data de Julgamento: 21/05/2014, Relator Ministro: Aloysio Corrêa da Veiga, 6 a Turma, Data de Publicação: DEJT 23/05/2014

${ }^{37}$ A disjunção ou concorrência é relativa à possibilidade de ajuizamento ou litisconsórcio, sem a anuência de outro legitimado, e não à possibilidade de coexistência de várias ações coletivas com o mesmo objeto, o que se tornou comum e acaba por atomizar as questões que deveriam ser processadas e decididas molecularmente. Ver em MENDES, Aluisio Gonçalves de Castro. Ações coletivas e meios de resolução coletiva de conflitos no direito comparado e nacional, $3^{\mathrm{a}}$ ed., São Paulo: Revista dos Tribunais, 2012, pp. 293.

${ }^{38}$ Nesse sentido, o citado acórdão do Recurso Extraordinário n. 573.232. Em voto vencido, o Sr. Min. Joaquim Barbosa asseverou que não haveria empecilho para que o associado que não autorizou expressamente a propositura da demanda, seja individualmente ou quando da assembleia, se beneficiasse do provimento jurisdicional que lhe foi favorável. A seu ver, "o art. $5^{\circ}$, XXI, da Constituição Federal de 1988, veicula hipótese de representação processual, razão por que a previsão estatutária e a expressa autorização dada pelos seus integrantes em assembleia da associação são pressupostos processuais para aferição de sua capacidade para estar no processo em defesa de direitos individuais homogêneos de seus integrantes. Contudo, tendo-se em vista a peculiaridade dos limites subjetivos da coisa julgada formada na ação coletiva, entendo que inexiste violação ao art. $5^{\circ}$, XXI, se o título judicial for utilizado para propositura de execução individual por associado que não concorreu para a deliberação favorável ao ajuizamento da demanda." O Relator Sr. Min. Ricardo Lewandowski também se pronunciou de maneira favorável ao associado em comento, mas por fundamentação diversa, in verbis: "A Constituição, como se vê, em nenhum momento exigiu que se colha uma autorização individual dos filiados para cada ação a ser ajuizada pelas associações, pois isso esvaziaria a importante atribuição que o constituinte originário cometeu a tais entidades, isto é, a de defender o interesse de seus membros." Assim, a autorização exigida poderia materializar-se por meio de decisão assemblear ou mediante previsão estatutária, pelo que qualquer filiado pode promover a execução da sentença, desde que sua pretensão esteja compreendida no âmbito da eficácia subjetiva do título judicial.
} 
Revista Eletrônica de Direito Processual - REDP. Volume 15. Janeiro a Junho de 2015 Periódico Semestral da Pós-Graduação Stricto Sensu em Direito Processual da UERJ. Patrono: José Carlos Barbosa Moreira. www.redp.com.br ISSN 1982-7636 PP 42-73

Claro que as ações ajuizadas por associações para defesa de direitos e interesses difusos e coletivos stricto sensu, ou seja, no caso de direitos indivisíveis, não despertam a discussão ora posta, pois o caráter incindível do bem da vida pleiteado não comportaria cumprimento individualizado da condenação imposta e, por conseguinte, tal discussão seria despida de utilidade, especialmente porque a legislação processual já lhe deu solução consentânea (art. 16, da Lei n. 4.717/65; art. 15, da LACP; art. 100, do CDC). Também por essa razão, as associações podem defender interesses transindividuais que ultrapassem os de seus associados. Isso é inevitável, dado o caráter indivisível dos interesses difusos e coletivos stricto sensu.

Quando se trata de interesses individuais homogêneos, surge a controvérsia acerca da possibilidade de o proveito obtido ser alcançado pelos não associados do legitimado.

Pelo teor do artigo 103, III, do CDC, que dispõe que, nessas hipóteses, a procedência do pedido terá efeitos erga omnes, para beneficiar todas as vítimas e seus sucessores, nada impediria que a associação civil postulasse em juízo em favor de todos aqueles que se encontrassem na situação alcançada por seus fins, ainda que não fossem associados. ${ }^{39}$ Há diversos acórdãos do STJ em consonância com o que se propõe $e^{40}$, mas, porque anteriores ao citado julgamento do RE 573.232, fica a ressalva da necessidade de autorização expressa do substituído, seja individual ou coletiva.

Por fim, ressalte-se que, em matéria de tutela coletiva aflorada por ações intentadas por associações, outra limitação exsurge da previsão do artigo $2^{\circ}$-A, caput e $\S$ único, da Lei n. 9.494/97. Confira-se:

Art. 2o-A. A sentença civil prolatada em ação de caráter coletivo proposta por entidade associativa, na defesa dos interesses e direitos dos seus associados, abrangerá apenas os substituídos que tenham, na data da propositura da ação, domicílio no âmbito da competência territorial do órgão prolator.(Incluído pela Medida provisória $\mathrm{n}^{\mathrm{o}} 2.180-35$, de 2001)

Parágrafo único. Nas ações coletivas propostas contra a União, os Estados, o Distrito Federal, os Municípios e suas autarquias e

39 Ver MAZZILli, Hugo Nigro. "A Defesa dos Interesses Difusos em Juízo”: meio ambiente, consumidor, patrimônio cultural, patrimônio público e outros interesses”, 22ed. Rev, ampl. e atual. São Paulo: Saraiva, 2009, p. 317.

${ }^{40}$ REsp 157.713 / RS, REsp 302.192 / RJ, REsp 132.724 / RS, REsp 72.994 / SP, REsp 132.502 / RS. 
Revista Eletrônica de Direito Processual - REDP. Volume 15. Janeiro a Junho de 2015 Periódico Semestral da Pós-Graduação Stricto Sensu em Direito Processual da UERJ. Patrono: José Carlos Barbosa Moreira. www.redp.com.br ISSN 1982-7636 PP 42-73

fundações, a petição inicial deverá obrigatoriamente estar instruída com a ata da assembléia da entidade associativa que a autorizou, acompanhada da relação nominal dos seus associados e indicação dos respectivos endereços. (Incluído pela Medida provisória $\mathrm{n}^{\circ}$ 2.180-35, de 2001)

Não obstante o primeiro movimento de interpretação da referida regra ter sido deveras negativo, atualmente o entendimento do Superior Tribunal de Justiça a respeito mostra-se cristalino no sentido de reconhecer que os limites objetivos e subjetivos da coisa julgada em nada se relacionam com o conceito ou os critérios de definição de competência. Em outras palavras, no que se prende à abrangência da sentença prolatada em ação civil pública, bem aquela relativa a direitos individuais homogêneos, o STJ pacificou, inclusive, em sede de recurso repetitivo, que "os efeitos e a eficácia da sentença não estão circunscritos a lindes geográficos, mas aos limites objetivos e subjetivos do que foi decidido, levando-se em conta, para tanto, sempre a extensão do dano e a qualidade dos interesses metaindividuais postos em juízo" 41

Mesmo antes da pacificação da controvérsia pelo STJ, o Tribunal Superior do Trabalho já deixava entrever sua simpatia por interpretações outras que não comprometessem a eficácia do resultado da lide coletiva, conjugando os artigos 103, I e II, da Lei 8078/90 e 21 da Lei de Ação Civil Pública para a superação da literalidade do artigo 16 da mesma lei ${ }^{42}$.

No TST a melhor interpretação só fez se fortalecer ao longo dos últimos anos ${ }^{43}$, podendo-se afirmar com segurança que o fantasma da decisão localizada e presa a um determinado território não mais assombra a tutela efetiva dos direitos coletivos, quer na seara cível, quer em julgados proferidos na Justiça do Trabalho.

Neste contexto, parece de relevante destaque pontuar que seja o dano de escala local, regional ou nacional, o juízo competente para proferir sentença, consciente da capilaridade ilimitada de seu provimento por todo o território sujeito à jurisdição brasileira, deverá lançar mão de comando capaz de recompor ou indenizar tais danos levando-se em consideração os beneficiários concretos do comando.

\footnotetext{
${ }^{41}$ Confiram-se os seguintes julgados de onde se extraiu o texto entre aspas: Recurso Repetitivo REsp 1391198 / RS e Recurso Repetitivo REsp 1243887 / PR

${ }^{42}$ RR-47100-77.2002.5.03.0096, Rel. Min. Maria de Assis Calsing, 4a Turma, DEJT 13/03/2009

${ }^{43}$ Ver RR-155485-67.2003.5.15.0091 e RR-157400-94.2004.5.01.0063,
} 
Revista Eletrônica de Direito Processual - REDP. Volume 15. Janeiro a Junho de 2015 Periódico Semestral da Pós-Graduação Stricto Sensu em Direito Processual da UERJ. Patrono: José Carlos Barbosa Moreira. www.redp.com.br ISSN 1982-7636 PP 42-73

Feita a necessária ponderação, vale reiterar que a restrição territorial em comento - ainda que por hipótese fosse sustentável - jamais operará efeitos no que diz respeito às ações coletivas que visam a proteger interesses difusos ou coletivos stricto sensu; hipóteses em que a extensão dos efeitos a toda categoria decorre naturalmente do efeito da sentença prolatada. ${ }^{44}$

Defender o contrário, isto é, proibir a atuação de uma entidade associativa em defesa dos interesses transindividuais de seus associados que não tenham domicílio "no âmbito da competência territorial do órgão prolator" seria inconstitucional, na medida em que equivaleria à denegação do seu acesso coletivo à jurisdição. Exigir a propositura de uma ação coletiva em cada comarca do país implica a inviabilização da defesa coletiva do direito. Com isso, o grupo lesado deixaria de gozar do efetivo acesso à justiça.

Do mesmo modo, a exigência mencionada no parágrafo único do artigo transcrito não se aplica em relação aos órgãos da justiça que tenham jurisdição nacional, haja vista que abrangem todos os substituídos, independentemente do seu domicílio. ${ }^{45}$

Finalmente, definido o alcance dos efeitos da decisão, importante frisar que, diante da sentença condenatória, a associação tem o prazo de sessenta dias para iniciar a respectiva execução. Se inerte, o artigo 15 , da LACP prevê a legitimidade dos demais entes para a promoção da execução do julgado, dentre eles, o Ministério Público, que possui o dever institucional de fazê-lo e não mera faculdade, caso dos demais.

\section{CONCLUSÃO.}

A necessidade de processos supraindividuais não é nova, há muito ocorrem lesões a direitos que atingem coletividades, grupos ou certa quantidade de indivíduos, que poderiam pleitear seus direitos de modo coletivo. Tais relações de massa se expandem continuamente e aí reside a diferença: dita expansão é acompanhada do crescimento dos problemas correlatos na mesma proporção, fruto do aumento da produção, dos meios de comunicação e do consumo, de servidores públicos e trabalhadores, aposentados e pensionistas etc.

\footnotetext{
${ }^{44}$ Ver em STJ, 3a Seção, CC n. ${ }^{\text {a } 109435 ~ / ~ P R . ~ R e l . ~ M i n . ~ N a p o l e a ̃ o ~ N u n e s ~ M a i a ~ F i l h o, ~ j . ~ 22.09 .2010 . ~}$

${ }^{45}$ Nesse sentido, RMS 23.566 / DF, j. 19.02.02, rel. Min. Moreira Alves, Informativo STF 258.
} 
Revista Eletrônica de Direito Processual - REDP. Volume 15. Janeiro a Junho de 2015 Periódico Semestral da Pós-Graduação Stricto Sensu em Direito Processual da UERJ. Patrono: José Carlos Barbosa Moreira. www.redp.com.br ISSN 1982-7636 PP 42-73

A massificação das relações interpessoais e sua influência no ordenamento processual brasileiro somente foram percebidas no início dos anos 80 , quando surgiu a efetiva e concreta preocupação com a proteção dos interesses coletivos lato sensu.

Limitadas as ações coletivas de competência da Justiça do Trabalho, de acordo com o artigo 114 da Constituição Federal, em (i) dissídios coletivos e (ii) demais possíveis ações coletivas de qualquer outra natureza procedimental e relacionados os inúmeros benefícios da busca pela tutela de forma coletiva em detrimento da individual, concluímos ser plenamente possível o ajuizamento das mais diversas modalidades de ações coletivas pelas associações de empregados.

Os requisitos legais exigidos para a respectiva atuação jurisdicional na defesa dos direitos e interesses de seus associados são: (i) pré-constituição há no mínimo um ano, que pode ser excepcionalmente dispensado; (ii) previsão institucional da defesa dos interesses e direitos difusos, coletivos e individuais homogêneos; (iv) pertinência temática, vale dizer: adequação entre o objeto da ação e a finalidade institucional; e (iv) autorização expressa dos substituídos para a atuação em juízo.

\section{REFERÊNCIAS BIBLIOGRÁFICAS}

BARBOSA, Maria da Graça Bonança. Ação coletiva trabalhista: novas perspectivas. São Paulo: LTr, 2010.

BARROS, Cássio Mesquita. "Representação dos trabalhadores no grupo de empresas”, in: Revista LTr. São Paulo, ano 63, n. 02, fevereiro de 1999, p. 162-163.

BARROS, Veronica Altef. "A representação dos trabalhadores prevista no art. 11 da CF/88 e a reforma sindical”, in: Revista Jurídica UNIJUS. Minas Gerais, vol. 10, n. 13, novembro de 2007, p. 193-212.

Borba, Joselita Nepomuceno. "Legitimidade concorrente: inexistência de monopólio do sindicato na defesa de interesses de integrantes da categoria". In: Revista do Ministério Público do Trabalho, v. 21, n. 43, p. 128-152, mar. 2012.

BORENFREUND, Georges. "Propos sur la représentativité syndicale”, in: Droit Social,n. 06, juin 1988, p. 476-488.

DELGADO, Mauricio Godinho. Direito Coletivo do Trabalho. $5^{\mathrm{a}}$ ed., São Paulo: LTr, 2014. 
Revista Eletrônica de Direito Processual - REDP. Volume 15. Janeiro a Junho de 2015 Periódico Semestral da Pós-Graduação Stricto Sensu em Direito Processual da UERJ. Patrono: José Carlos Barbosa Moreira. www.redp.com.br ISSN 1982-7636 PP 42-73

FREDIANI, Yone. "A representação dos trabalhadores no local de trabalho e a reforma sindical", in: Revista de Direito do Trabalho. São Paulo, vol. 119, julho de 2005, p. 205.

MAGANO, Octavio Bueno. "Representação profissional e política do trabalhador e do empresário”, in: Revista de Direito do Trabalho, vol. 20, julho de 1979, p. 153.

MANNRICH, Nelson. "Representação dos trabalhadores na empresa”, in: Revista LTr. São Paulo, ano 61, n. 09, setembro de 1997, p. 1181-1186.

MORAES, Aldenise Paula de Freitas. "A legitimidade dos sindicatos e das associações na defesa dos direitos coletivos dos trabalhadores", in: Revista do Direito do Trabalho, vol. 150, março de 2013, p. 149.

ROMITA, Arion Sayão. "A representação dos trabalhadores na empresa", in: Jurisprudência brasileira trabalhista - JBT 34, p. 19-30.

SANTOS, Ronaldo Lima dos. Sindicatos e Ações Coletivas: acesso à justiça, jurisdição coletiva e tutela dos interesses difusos, coletivos e individuais homogêneos. $4^{\mathrm{a}}$ ed., São Paulo: LTr, 2014.

SUSSEKIND, Arnaldo. "Substituição processual ou representação legal exercida de oficio?”, in: Revista LTr. São Paulo, ano 57, n. 09, setembro de 1993, p. 1039-1042.

TESHEINER, José Maria. “Aplicação do Direito objetivo e tutela de direitos subjetivos nas ações transindividuais e homogeneizantes". In Revista Brasileira de Direito Processual - RBDPro, Belo Horizonte: Editora Fórum, ano 20, n. 78, 13-28, abr/jun. 2012. 